\title{
Morphometric Characters and Meristic Counts of Black Chin Tilapia (Sarotherodon melanotheron) From Buguma, Ogbakiri and Elechi Creeks, Rivers State, Nigeria
}

\author{
Akinrotimi $\mathbf{O A}^{\mathbf{1}^{*}}$, Ukwe $\mathrm{OIK}^{2}$ and Amadioha $\mathrm{F}^{3}$ \\ ${ }^{1}$ African Regional Aquaculture Center of Nigerian Institute for Oceanography and Marine Research, Port Harcourt, Rivers \\ State, Nigeria \\ ${ }^{2,3}$ Department of Fisheries, Faculty of Agriculture, Rivers State University of Science and Technology, Nkpolu-Oroworkwo, \\ Port Harcourt, Rivers State, Nigeria
}

\begin{abstract}
Received: December 04, 2017; Accepted: January 06, 2018; Published: January 09, 2018
*Corresponding author: Akinrotimi OA, African Regional Aquaculture Centre of Nigerian Institute for Oceanography and Marine Research, Port Harcourt, Rivers State, Nigeria, Tel: +2348065770699; E-mail:ojoakinrotimi@gmail.com
\end{abstract}

\begin{abstract}
An experiment was carried out to assess the morphometric measurements and meristic counts of black jaw tilapia, Sarotherodon melanotheron (Ruppell, 1852) from Buguma, Ogbakiri and Elechi creeks, Rivers State, Nigeria. The study was done to determine racial variations between this specie in the three environments. Fifty specimens were collected monthly from each location between April and June 2017. The results revealed that they were phenotypically separable populations of the same species. Significant differences $(P<$ 0.05 ) were recorded in body depth, and caudal peduncle length in each month between the fish sampled from Buguma and other two creeks, which were suggested to have occurred as a result of difference in the environmental conditions in the three creeks. The results also implied that fish from Buguma creek could be preferable as brood stock for breeding programmes.
\end{abstract}

Key words: Tilapia; Morphometrics; Meristics; Racial Variations; Niger Delta;

\section{Introduction}

Tilapia culture has increased in Nigeria in recent times. This is particularly because of its fast growth and the fact that it can easily reproduced in many confined water bodies throughout the country [1]. However, after decades of introduction and domestication of the fish, they have highly adapted to a wide range of geographical locations and have shown phenotypic variations with respect to the pure tilapia strains of the brood stock [2]. This may be due to the effects of the environment or due to the hybrids evolved through extensive intra breeding [3]. In this context, natural morphometric/meristic data are of great importance for improvement of aquaculture. Morphometric and the meristic methods remains the simplest and most direct methods of species identification [4]. Analysis of phenotypic variation in morphometric characters or meristic counts remains the most commonly used method to delineate stocks of fish despite the advent of techniques which directly examines biochemical or molecular genetic variation, these conventional methods continues to have an important role in stock identification even to date [5]. Morphological differences based on general body type or unusual anatomical forms have been used to distinguish and compare among species and groups dimensions have been used to describe fish body shape [6].

Identification of species is a primary step towards any research work and plays a key role for the behavioral study. Morphometric measurements and meristic counts are considered as easiest and authentic methods for the identification of specimen which is termed as morphological systematic [7]. Morphological measurements, meristic counts, provide data useful for taxonomic status [8]. In general, fish demonstrate greater variances in morphological traits both within and between populations than other vertebrates and are more susceptible to environmentally induced morphological variations. The cause of variation in the morphometric and meristic characters may range from variability to the intraspecific which is under the influence of environmental parameters [9]. The morphometric relationships between various body parts of fish can be used to assess the well being of individuals and to determine possible difference between separate unit stocks of the same species [10]. Fish are very sensitive to environmental changes and quickly adapt themselves by changing necessary morphometrics [11]. Information on the morphometric measurements of fishes and the study of statistical relationship among them are essential for taxonomic work.

Sarotherodon melanotheron (Ruppell, 1852) is typical estuarine specie which can be found in abundance in most of the lagoons, creeks and estuaries of West Africa and supports a major lagoon fishery [12]. They can live and reproduce in a wide range of salinities. They have adapted to diverse habitats such as permanent and temporary rivers, large equatorial lakes, tropical and subtropical rivers, open and closed estuaries, lagoons, swampy lakes, deep lakes and coastal brackish lakes [13]. These fishes have a great economic importance, ranking among the major species caught within the brackish water areas and there is an increasing interest in this fish for aquaculture purposes, particularly in areas of high or variable salinities, characteristic 
of the estuaries and extensive lagoon systems which constitute its natural range [14]. In most parts of Niger Delta, an assessment of morphometric differentiation of indigenous fish species has not been exploited. Therefore, the present investigation is aimed at examining the morphormetrics and meritic variability in $\mathrm{S}$. melanotheron from three creeks (Buguma, Ogbakiri and Elechi) in Rivers State, Niger Delta, Nigeria. This study will provide information on the contribution and effect of environmental factors to the morphomeristic characteristics of these species.

\section{Materials and Methods}

\section{Research Place and Duration}

The research was conducted in the laboratory of the Department of Fisheries and Aquatic Environment, Rivers State University, Port Harcourt, from April to June, 2017.

\section{Sampling Location}

The samples was collected monthly from Buguma, Ogbakiri and Elechi Creeks, in Rivers State, Nigeria they were located on the lower reaches of New Calabar River (Figure 1).

Elechi Creek, South-West of Port Harcourt metropolis, lies between longitude $6^{\circ} 45^{\prime \prime} \mathrm{E}$ and $7^{\circ} 20^{\prime \prime} \mathrm{N}$ and latitude $4^{\circ} 38^{\prime \prime} \mathrm{N}$ and $5^{\circ} 5^{\prime \prime} \mathrm{E}$. The creek is a tributary of the upper limits of Bonny Estuary and includes its adjoining mangrove Creeks situated near the Eagle Island by the Rivers State University of Science and Technology, Nkpolu, Port Harcourt (Figure 1). The vegetation is predominantly mangrove. While Buguma creek is located in Asari Toru Local Government Area of Rivers State. It is located between longitude $60^{\circ} 47^{\prime} \mathrm{E}$ and $60^{\circ} 59^{\prime} \mathrm{E}$ and $40^{\circ} 36^{\prime} \mathrm{N}$ and $40^{\circ} 59^{\prime} \mathrm{N}$ The Buguma creeks systems consist of the main creek channel and associated inter connecting creeks, which interconnect and surround Buguma and other communities. Ogbakiri creek is located in the lower reaches of New Calabar River. This area consist of some settlements/communities whose main activities is fishing and cultivation of crops which are their source of livelihood

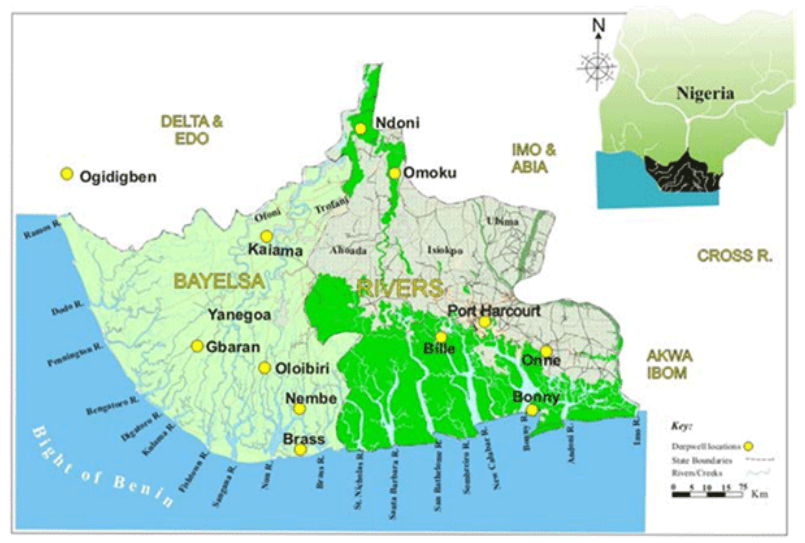

Figure 1: Map of Niger Delta Showing the Sampling Sites.

\section{Sample Collection}

A total of fifty (50) specimens of $S$. melanotheron were collected monthly from fishermen catch in the three creeks. Collected samples were placed individually into plastic bags and kept in ice box, until transportation to the laboratory. The specimens were transported in ice chest to the laboratory, where measurements started immediately to avoid shrinkage.

\section{Morphometrics and Meristic Measurement}

For each fish, nine morphometric measurements (Table 1), was made to the nearest centimetre, using divider, transparent ruler and a measuring board. The meristic counts (Table 2), was carried out by counting the number of soft rays on five fins on the body of the fish

\begin{tabular}{|l|l|l|}
\hline \multicolumn{2}{|l|}{ Table 1: Morphometric Characters Descriptions of S.melanotheron } \\
\hline Characters & \multicolumn{1}{|l|}{ Descriptions } \\
\hline 1. & Total length (TL) & $\begin{array}{l}\text { Distance from the tip of the snout to the } \\
\text { longest caudal fin ray }\end{array}$ \\
\hline 2. & Standard length (SL) & $\begin{array}{l}\text { Distance from the tip of the snout to the } \\
\text { end of the vertebral column }\end{array}$ \\
\hline 3. & Head length (HL) & $\begin{array}{l}\text { Distance from the tip of the snout to the } \\
\text { posterior margin of the opercula }\end{array}$ \\
\hline 4. & Eye Diameter (ED) & Diameter of the eye \\
\hline 5. & $\begin{array}{l}\text { Caudal Peduncle } \\
\end{array}$ & Length(CPL) \\
\hline 6. & $\begin{array}{l}\text { Pre Dorsal Length } \\
\text { (PrDL) }\end{array}$ & $\begin{array}{l}\text { Length of the peduncle } \\
\text { the dorsal fin base }\end{array}$ \\
\hline 7. & $\begin{array}{l}\text { Pre Orbital Length } \\
\text { (PrOL) }\end{array}$ & $\begin{array}{l}\text { From tip of snout to anterior margin } \\
\text { of eye }\end{array}$ \\
\hline 8. & $\begin{array}{l}\text { Post Orbital Length } \\
\text { (POL) }\end{array}$ & $\begin{array}{l}\text { From posterior margin of the eye to } \\
\text { posterior margin of opercula }\end{array}$ \\
\hline 9. & $\begin{array}{l}\text { Maximum Body Depth } \\
\text { (MBD }\end{array}$ & $\begin{array}{l}\text { The vertical distance between the } \\
\text { dorsal and ventral margins of the }\end{array}$ \\
\hline
\end{tabular}

Table 2: Meristics Measurements and the Abbreviations

\begin{tabular}{|l|l|}
\hline \multicolumn{1}{|c|}{ Characters } & \multicolumn{1}{c|}{ Abbreviations } \\
\hline 1. Number of the Dorsal fin soft rays & DFR \\
\hline 2. Number of Anal fin soft rays & AFS \\
\hline 3. Number of Caudal Fin Soft Rays & CFR \\
\hline 4. Number of the Pectoral fin soft rays & PFR \\
\hline 5. Number of Pelvic Soft Fin Rays & PVR \\
\hline
\end{tabular}

\section{Evaluation of Water Quality Parameters}

During the study, the following water quality parameters temperature, hydrogen ion concentration $(\mathrm{pH})$, dissolved oxygen (DO), and salinity were monitored monthly in the different creeks. Water temperature measurement was taken in situ by using mercury in glass thermometer $\left({ }^{\circ} \mathrm{C}\right)$. Hydrogen ion concentration $(\mathrm{pH})$ was determined in situ by the use of a $\mathrm{pH}$ meter (Model HI 9812, Hannah Products, and Portugal). These were done by dipping one end of the instrument in the water. Sufficient time 
(2 minutes) was allowed for it to reach a constant reading, before the readings were recorded. Salinity values were determined in situ by using a hand held Refract meter (Model RE 6783, Atago Products, and Portugal). The values of the dissolved oxygen were determined with the method described by APHA [15].

\section{Statistical Analysis}

Data generated was collated and statistical analysis of the morphometric and meristics features was based on a one way analysis of variance (ANOVA).

\section{Results}

\section{Physico Chemical Parameters of Water in the Sampling Creeks}

The result of the physicochemical analysis of water from Buguma, Ogbakiri and Elechi creeks in the month of April is presented in table 3. The results revealed that the values of dissolved oxygen, $\mathrm{pH}$ and salinity were significantly $(\mathrm{p}<0.05)$ higher in Buguma Creek than Ogbakiri and Elechi Creeks. While water temperature recorded in this study were within the same range of $29.00-30.10 \mathrm{C}$. The same trend was recorded in the months of May and June in the sampling Creeks. (Tables 4 $5)$. The summary of the water quality parameters in the three sampling months is shown in table 6. The highest values in all the parameters were recorded in Buguma Creek, while Elechi Creek had the lowest values.

Table 3: Physico-chemical Parameters in Buguma, Ogbakiri and Elechi Creeks in the Month of April (Mean \pm SD)

\begin{tabular}{|l|l|l|l|}
\hline Parameters & $\begin{array}{l}\text { Buguma } \\
\text { Creek }\end{array}$ & $\begin{array}{l}\text { Ogbakiri } \\
\text { Creek }\end{array}$ & Elechi Creek \\
\hline Temperature (OC) & $30.12 \pm 2.56^{\mathrm{a}}$ & $30.12 \pm 2.56^{\mathrm{a}}$ & $30.12 \pm 2.56^{\mathrm{a}}$ \\
\hline DO(mg/L) & $5.89 \pm 0.99^{\mathrm{b}}$ & $5.89 \pm 0.99^{\mathrm{b}}$ & $5.89 \pm 0.99^{\mathrm{b}}$ \\
\hline pH & $7.42 \pm 1.23^{\mathrm{b}}$ & $7.42 \pm 1.23^{\mathrm{b}}$ & $7.42 \pm 1.23^{\mathrm{b}}$ \\
\hline Salinity (\%o) & $15.88 \pm 2.98^{\mathrm{c}}$ & $15.88 \pm 2.98^{\mathrm{c}}$ & $15.88 \pm 2.98^{\mathrm{c}}$ \\
\hline
\end{tabular}

Means in the same roll with different superscripts are significantly different $(p<0.05)$

Table 4: Physico-chemical Parameters in Buguma, Ogbakiri and Elechi Creeks in the Month of May (Mean \pm SD)

\begin{tabular}{|l|l|l|l|}
\hline Parameters & $\begin{array}{l}\text { Buguma } \\
\text { Creek }\end{array}$ & $\begin{array}{l}\text { Ogbakiri } \\
\text { Creek }\end{array}$ & Elechi Creek \\
\hline Temperature (OC) & $29.05 \pm 3.66^{\mathrm{a}}$ & $28.66 \pm 3.08^{\mathrm{a}}$ & $28.75 \pm 2.45^{\mathrm{a}}$ \\
\hline DO(mg/L) & $5.14 \pm 1.01^{\mathrm{b}}$ & $4.44 \pm 1.23^{\mathrm{a}}$ & $4.52 \pm 0.95^{\mathrm{a}}$ \\
\hline pH & $7.51 \pm 1.02^{\mathrm{b}}$ & $6.49 \pm 1.08^{\mathrm{a}}$ & $6.61 \pm 1.01^{\mathrm{a}}$ \\
\hline Salinity (\%o) & $14.02 \pm 2.05^{\mathrm{c}}$ & $7.89 \pm 1.11^{\mathrm{a}}$ & $8.23 \pm 1.21^{\mathrm{b}}$ \\
\hline
\end{tabular}

Means in the same roll with different superscripts are significantly different $(p<0.05)$
Table 5: Physico-chemical Parameters in Buguma, Ogbakiri and Elechi Creeks in the Month of June (Mean \pm SD)

\begin{tabular}{|l|c|c|c|}
\hline Parameters & $\begin{array}{c}\text { Buguma } \\
\text { Creek }\end{array}$ & $\begin{array}{c}\text { Ogbakiri } \\
\text { Creek }\end{array}$ & Elechi Creek \\
\hline Temperature (OC) & $29.78 \pm 2.41^{\mathrm{a}}$ & $27.99 \pm 3.77^{\mathrm{a}}$ & $28.02 \pm 2.07^{\mathrm{a}}$ \\
\hline DO(mg/L) & $5.24 \pm 1.04^{\mathrm{b}}$ & $4.47 \pm 1.73^{\mathrm{a}}$ & $4.43 \pm 0.87^{\mathrm{a}}$ \\
\hline pH & $7.47 \pm 1.93^{\mathrm{b}}$ & $6.62 \pm 1.23^{\mathrm{a}}$ & $6.74 \pm 1.43^{\mathrm{a}}$ \\
\hline Salinity (\%o) & $14.18 \pm 2.03^{\mathrm{b}}$ & $7.02 \pm 1.03^{\mathrm{a}}$ & $7.98 \pm 1.02^{\mathrm{a}}$ \\
\hline
\end{tabular}

Means in the same roll with different superscripts are significantly different $(p<0.05)$

Table 6: Summary of Physico-chemical Parameters in Buguma, Ogbakiri and Elechi Creeks during the Sampling Period (Mean \pm SD)

\begin{tabular}{|l|c|c|c|}
\hline Parameters & Buguma Creek & Ogbakiri Creek & Elechi Creek \\
\hline $\begin{array}{l}\text { Temperature } \\
\text { (OC) }\end{array}$ & $29.79 \pm 1.09^{\mathrm{a}}$ & $28.97 \pm 1.10^{\mathrm{a}}$ & $28.92 \pm 1.2^{\mathrm{a}}$ \\
\hline DO(mg/L) & $5.97 \pm 0.17^{\mathrm{b}}$ & $4.48 \pm 0.19^{\mathrm{a}}$ & $4.42 \pm 0.32^{\mathrm{a}}$ \\
\hline
\end{tabular}

\section{Morphometric Values of $S$. melanotheron from Buguma, Ogbakiri and Elechi Creeks}

The results of the morphometric features of S. melanotheron from Buguma, Ogbakiri and Elechi Creeks in the month of April are shown in table 7. The result indicated that there were significant differences $(p<0.05)$ in the Total Length (TL), Standard Length (SL), Head Length (HL), Caudal Peduncle Length (CPL) and Maximum Body Depth (MBD), between the fish sampled from Buguma Creek and the other two creeks. In the month of May (Table 8), significant differences $(p<0.05)$ in the Total Length (TL), Standard Length (SL), Head Length (HL), Caudal Peduncle Length (CPL), Pre Orbital Length (PrOL), Post Orbital Length (PrDL) and Maximum Body Depth (MBD), were observed in Buguma Creek compared to other creeks.

Moreover, in the month of June, the result obtained indicated significant differences $(p<0.05)$ in the Head Length (HL), Caudal Peduncle Length (CPL) and Maximum Body Depth (MBD), between the fish sampled from Buguma Creek and the other two creeks (Table 9). The summary of morphometric measurement in all the creeks in the three sampling months is presented in table 10. Significant differences $(\mathrm{p}<0.05)$ were observed in the Total Length (TL), Standard Length (SL), Head Length (HL), Caudal Peduncle Length (CPL), Pre Orbital Length (PrOL) and Maximum Body Depth (MBD) in S.melanotheron sampled from Buguma, when compared to Ogbakiri and Elechi Creeks.

\section{Meristic Counts in S. melanotheron from Buguma, Ogbakiri and Elechi Creeks}

The mean values of meristic characters from Buguma Ogbakiri and Elechi creeks were shown in tables 11 to 14 . The fin rays including dorsal fin soft rays, anal fin soft rays, caudal fin soft rays, pectoral fin soft rays and pelvic soft fin rays were fairly constant in all the creeks throughout the three sampling months. 
Table 7: Morphometric Values of S. melanotheron from Buguma, Ogbakiri and Elechi Creeks in the Month of April (Mean \pm SD )

\begin{tabular}{|c|c|c|c|}
\hline Parameters (cm) & Buguma Creek & Ogbakiri Creek & Elechi Creek \\
\hline Total length (TL) & $15.54 \pm 2.71^{b}$ & $14.84 \pm 2.05^{a}$ & $14.23 \pm 2.23^{\mathrm{a}}$ \\
\hline Standard length (SL) & $12.31 \pm 2.07^{b}$ & $11.62 \pm 2.21^{\mathrm{a}}$ & $11.19 \pm 2.09^{\mathrm{a}}$ \\
\hline Head Length (HL) & $4.31 \pm 0.12^{\mathrm{b}}$ & $3.73 \pm 0.11^{\mathrm{a}}$ & $3.54 \pm 0.12^{\mathrm{a}}$ \\
\hline Eye Diameter (ED) & $0.61 \pm 0.02^{\mathrm{a}}$ & $0.73 \pm 0.07^{\mathrm{a}}$ & $0.54 \pm 0.02^{\mathrm{a}}$ \\
\hline Caudal Peduncle Length(CPL) & $2.82 \pm 0.01^{\mathrm{b}}$ & $1.74 \pm 0.04^{\mathrm{a}}$ & $1.67 \pm 0.02^{\mathrm{a}}$ \\
\hline Pre Dorsal Length (PrDL) & $1.82 \pm 0.01^{\mathrm{a}}$ & $1.74 \pm 0.04^{\mathrm{a}}$ & $1.67 \pm 0.02^{\mathrm{a}}$ \\
\hline Pre Orbital Length (PrOL) & $4.02 \pm 0.09^{a}$ & $3.87 \pm 0.08^{\mathrm{a}}$ & $3.76 \pm 0.01^{\mathrm{a}}$ \\
\hline Post Orbital Length (POL) & $2.01 \pm 0.05^{\mathrm{a}}$ & $1.87 \pm 0.04^{\mathrm{a}}$ & $1.86 \pm 0.05^{\mathrm{a}}$ \\
\hline
\end{tabular}

Table 8: Morphometric Values of S. melanotheron from Buguma, Ogbakiri and Elechi Creeks in the Month of May (Mean \pm SD )

\begin{tabular}{|c|c|c|c|}
\hline Parameters (cm) & Buguma Creek & Ogbakiri Creek & Elechi Creek \\
\hline Total length (TL) & $15.43 \pm 1.88^{b}$ & $15.24 \pm 2.45^{b}$ & $14.78 \pm 2.14^{\mathrm{a}}$ \\
\hline Standard length (SL) & $12.84 \pm 2.03^{\mathrm{b}}$ & $12.53 \pm 2.53^{\mathrm{b}}$ & $11.84 \pm 2.11^{\mathrm{a}}$ \\
\hline Head Length (HL) & $4.11 \pm 0.22^{\mathrm{b}}$ & $3.93 \pm 0.13^{\mathrm{a}}$ & $3.84 \pm 0.19^{a}$ \\
\hline Eye Diameter (ED) & $0.72 \pm 0.03^{\mathrm{a}}$ & $0.69 \pm 0.08^{\mathrm{a}}$ & $0.64 \pm 0.08^{\mathrm{a}}$ \\
\hline Caudal Peduncle Length(CPL) & $1.77 \pm 0.21^{\mathrm{a}}$ & $1.76 \pm 0.33^{\mathrm{a}}$ & $1.77 \pm 0.12^{\mathrm{a}}$ \\
\hline Pre Dorsal Length (PrDL) & $1.92 \pm 0.06^{\mathrm{a}}$ & $1.84 \pm 0.14^{\mathrm{a}}$ & $1.81 \pm 0.54^{\mathrm{a}}$ \\
\hline Pre Orbital Length (PrOL) & $4.86 \pm 0.23^{\mathrm{b}}$ & $3.75 \pm 0.65^{\mathrm{a}}$ & $3.77 \pm 0.41^{\mathrm{a}}$ \\
\hline Post Orbital Length (POL) & $2.92 \pm 0.06^{\mathrm{b}}$ & $1.89 \pm 0.24^{\mathrm{a}}$ & $1.86 \pm 0.02^{\mathrm{a}}$ \\
\hline \multicolumn{4}{|c|}{ Means within the same roll with different superscripts are significantly different $(P<0.05)$} \\
\hline \multicolumn{4}{|c|}{ Table 9: Morphometric Values of S. melanotheron from Buguma, Ogbakiri and Elechi Creeks in the Month of June (Mean \pm SD ) } \\
\hline Parameters (cm) & Buguma Creek & Ogbakiri Creek & Elechi Creek \\
\hline Total length (TL) & $15.05 \pm 1.98^{\mathrm{a}}$ & $14.89 \pm 2.55^{\mathrm{a}}$ & $14.85 \pm 2.94^{\mathrm{a}}$ \\
\hline Standard length (SL) & $12.06 \pm 2.11^{\mathrm{a}}$ & $11.53 \pm 2.21^{\mathrm{a}}$ & $11.94 \pm 2.34^{\mathrm{a}}$ \\
\hline Head Length (HL) & $4.61 \pm 0.13^{\mathrm{b}}$ & $4.53 \pm 0.47^{\mathrm{a}}$ & $4.73 \pm 0.41^{\mathrm{a}}$ \\
\hline Eye Diameter (ED) & $0.59 \pm 0.12^{\mathrm{a}}$ & $0.69 \pm 0.18^{\mathrm{a}}$ & $0.61 \pm 0.118^{\mathrm{a}}$ \\
\hline Caudal Peduncle Length(CPL) & $2.57 \pm 0.11^{\mathrm{b}}$ & $1.68 \pm 0.13^{\mathrm{a}}$ & $1.66 \pm 0.22^{\mathrm{a}}$ \\
\hline Pre Dorsal Length (PrDL) & $1.82 \pm 0.01^{\mathrm{a}}$ & $1.74 \pm 0.04^{\mathrm{a}}$ & $1.67 \pm 0.02^{\mathrm{a}}$ \\
\hline Post Orbital Length (POL) & 1.82 & $1.88 \pm 0.14^{\mathrm{a}}$ & $1.73 \pm 0.11^{\mathrm{a}}$ \\
\hline Maximum Body Depth (MBD) & 5.41 & $4.68 \pm 0.71^{\mathrm{a}}$ & $4.39 \pm 0.34^{\mathrm{a}}$ \\
\hline
\end{tabular}


Table 10: Summary Of Morphometric Values of S. melanotheron From Buguma, Ogbakiri and Elechi Creeks in Three Sampling Months

\begin{tabular}{|c|c|c|c|}
\hline Parameters (cm) & Buguma Creek & Ogbakiri Creek & Elechi Creek \\
\hline Total length (TL) & $15.27 \pm 1.88^{b}$ & $13.94 \pm 2.32^{c}$ & $14.62 \pm 2.05^{b}$ \\
\hline Standard length (SL) & $12.30 \pm 3.65^{b}$ & $11.89 \pm 2.04^{\mathrm{a}}$ & $11.65 \pm 2.04^{\mathrm{a}}$ \\
\hline Head Length (HL) & $5.34 \pm 0.12^{\mathrm{b}}$ & $4.06 \pm 0.31^{\mathrm{a}}$ & $4.03 \pm 0.11^{\mathrm{a}}$ \\
\hline Eye Diameter (ED) & $0.64 \pm 0.22^{\mathrm{a}}$ & $0.70 \pm 0.10^{\mathrm{a}}$ & $0.59 \pm 0.22^{\mathrm{a}}$ \\
\hline Caudal Peduncle Length(CPL) & $2.82 \pm 0.21^{\mathrm{b}}$ & $1.74 \pm 0.14^{\mathrm{a}}$ & $1.70 \pm 0.02^{\mathrm{a}}$ \\
\hline Pre Dorsal Length (PrDL) & $1.85 \pm 0.03^{\mathrm{a}}$ & $1.77 \pm 0.08^{\mathrm{a}}$ & $1.71 \pm 0.01^{\mathrm{a}}$ \\
\hline Pre Orbital Length (PrOL) & $4.04 \pm 0.01^{\mathrm{b}}$ & $3.83 \pm 0.04^{\mathrm{a}}$ & $3.75 \pm 0.01^{\mathrm{a}}$ \\
\hline Post Orbital Length (POL) & $1.91 \pm 0.05^{\mathrm{a}}$ & $1.87 \pm 0.01^{\mathrm{a}}$ & $1.78 \pm 0.04^{\mathrm{a}}$ \\
\hline Maximum Body Depth (MBD) & $5.84 \pm 0.05^{\mathrm{b}}$ & $4.74 \pm 0.01^{\mathrm{a}}$ & $4.47 \pm 0.04^{\mathrm{a}}$ \\
\hline
\end{tabular}

Table 11: Meristic Counts in S. melanotheron from Buguma, Ogbakiri and Elechi Creeks in the Month of April (Mean \pm SD)

\begin{tabular}{|l|c|c|}
\hline Meristic Counts (No.) & Buguma Creek & Ogbakiri Creek \\
\hline Number of the Dorsal Fin Soft Rays & $11.01 \pm 1.03^{\mathrm{a}}$ & $11.02 \pm 0.05^{\mathrm{a}}$ \\
\hline Number of Anal Fin Soft Rays & $12.16 \pm 0.21^{\mathrm{a}}$ & $12.03 \pm 0.11^{\mathrm{a}}$ \\
\hline Number of Caudal Fin Soft Rays & $15.21 \pm 0.11^{\mathrm{a}}$ & $15.13 \pm 0.17^{\mathrm{a}}$ \\
\hline Number of the Pectoral Fin Soft Rays & $12.02 \pm 0.02^{\mathrm{a}}$ & $12.01 \pm 0.10^{\mathrm{a}}$ \\
\hline Number of Pelvic Soft Fin Rays & $5.07 \pm 0.01^{\mathrm{a}}$ & $15.23 \pm 0.21^{\mathrm{a}}$ \\
\hline
\end{tabular}

Means within the same roll with different superscripts are significantly different $(P<0.05)$

Table 12: Meristic Counts in S. melanotheron from Buguma, Ogbakiri and Elechi Creeks in the Month of May (Mean \pm SD)

\begin{tabular}{|c|c|c|c|}
\hline Meristic Counts (No.) & Buguma Creek & Ogbakiri Creek & Elechi Creek \\
\hline Number of the Dorsal Fin Soft Rays & $11.22 \pm 1.04^{\mathrm{a}}$ & $11.12 \pm 0.12^{\mathrm{a}}$ & $11.22 \pm 0.27^{\mathrm{a}}$ \\
\hline Number of Anal Fin Soft Rays & $12.24 \pm 0.42^{\mathrm{a}}$ & $12.12 \pm 0.57^{\mathrm{a}}$ & $12.31 \pm 0.12^{\mathrm{a}}$ \\
\hline Number of Caudal Fin Soft Rays & $15.62 \pm 0.42^{\mathrm{a}}$ & $15.54 \pm 0.28^{\mathrm{a}}$ & $15.62 \pm 0.42^{\mathrm{a}}$ \\
\hline Number of the Pectoral Fin Soft Rays & $12.01 \pm 0.01^{\mathrm{a}}$ & $12.21 \pm 0.10^{\mathrm{a}}$ & $12.21 \pm 0.16^{\mathrm{a}}$ \\
\hline
\end{tabular}

Means within the same roll with different superscripts are significantly different $(P<0.05)$

Table 13: Meristic Counts in S. melanotheron from Buguma, Ogbakiri and Elechi Creeks in the Month of June (Mean \pm SD)

\begin{tabular}{|l|c|c|c|}
\hline Meristic Counts (No.) & Buguma Creek & Ogbakiri Creek & Elechi Creek \\
\hline Number of the Dorsal Fin Soft Rays & $11.05 \pm 1.12^{\mathrm{a}}$ & $11.02 \pm 1.00^{\mathrm{a}}$ & $11.02 \pm 0.85^{\mathrm{a}}$ \\
\hline Number of Anal Fin Soft Rays & $12.54 \pm 0.33^{\mathrm{a}}$ & $12.64 \pm 0.65^{\mathrm{a}}$ & $12.34 \pm 0.11^{\mathrm{a}}$ \\
\hline Number of Caudal Fin Soft Rays & $15.43 \pm 0.25^{\mathrm{a}}$ & $15.62 \pm 0.29^{\mathrm{a}}$ & $15.02 \pm 0.55^{\mathrm{a}}$ \\
\hline Number of the Pectoral Fin Soft Rays & $12.12 \pm 0.31^{\mathrm{a}}$ & $12.41 \pm 0.37^{\mathrm{a}}$ & $12.44 \pm 0.38^{\mathrm{a}}$ \\
\hline Number of Pelvic Soft Fin Rays & $5.08 \pm 0.12^{\mathrm{a}}$ & $5.10 \pm 0.44^{\mathrm{a}}$ & $5.14 \pm 0.68^{\mathrm{a}}$ \\
\hline Means within the same roll with different superscripts are significantly different $(P<0.05)$
\end{tabular}

Citation: Akinrotimi OA, Ukwe OI, et al. (2018) Morphometric Characters and Meristic Counts of Black Chin Tilapia (Sarotherodon melanotheron) From Buguma, Ogbakiri and Elechi Creeks, Rivers State, Nigeria. Int J Poul Fish Sci 2(1): 1-8. DOI: 10.15226/2578$1898 / 2 / 1 / 00106$ 


\begin{tabular}{|l|c|c|c|}
\hline \multicolumn{2}{|l|}{ Table 14: Summary of Meristic Counts in S. melanotheron from Buguma, Ogbakiri and Elechi Creeks in the Three Sampling Months (Mean \pm SD ) } \\
\hline Meristic Counts (No.) & Buguma Creek & Ogbakiri Creek \\
\hline Number of the Dorsal Fin Soft Rays & $11.09 \pm 1.02^{\mathrm{a}}$ & $11.05 \pm 1.01^{\mathrm{a}}$ & $11.08 \pm 0.05^{\mathrm{a}}$ \\
\hline Number of Anal Fin Soft Rays & $12.31 \pm 0.03^{\mathrm{a}}$ & $12.26 \pm 0.04^{\mathrm{a}}$ & $15.43 \pm 0.03^{\mathrm{a}}$ \\
\hline Number of Caudal Fin Soft Rays & $15.42 \pm 0.05^{\mathrm{a}}$ & $12.21 \pm 0.07^{\mathrm{a}}$ & $15.29 \pm 0.04^{\mathrm{a}}$ \\
\hline Number of the Pectoral Fin Soft Rays & $12.05 \pm 0.01^{\mathrm{a}}$ & $12.22 \pm 0.07^{\mathrm{a}}$ & $5.06 \pm 0.04^{\mathrm{a}}$ \\
\hline Number of Pelvic Soft Fin Rays & $5.05 \pm 0.02^{\mathrm{a}}$ & $5.06 \pm 0.08^{\mathrm{a}}$ & \\
\hline
\end{tabular}

Means within the same roll with different superscripts are significantly different $(P<0.05)$

\section{Discussion}

The water quality parameters obtained in this study is typical of a brackish water environment. Hydrogen ion concentration $(\mathrm{pH})$ is an important parameter which determines the suitability of water for various purposes. The $\mathrm{pH}$ range of 6.3 to 7.7 observed in all the creeks could be considered as being within acceptable range for a brackish water system. The $\mathrm{pH}$ of brackish water bodies stated by Imevbore [16] ranged from 6.5 to 7.4, which fall within the range reported in this investigation. Also, Agbozu and Emperor [17] also reported a pH range of 7.48 to 8.89 in Abonnema creek in Rivers State, Nigeria. The $\mathrm{pH}$ values obtained for this study are within the limits to supports aquatic life as suggested by Boyd [18] for optimum fish and shrimp production. The $\mathrm{pH}$ was found to have slight variations between the creeks. Elevated pH was found in Buguma creek when compared to other creeks. The lower mean $\mathrm{pH}$ values obtained in the other two creeks may be associated with the high fresh water emptying into the creek from the adjoining swamp forest streams and municipal drains [19].

The water temperatures recorded in this study were within the same range in the sampling months in all creeks. This agrees with the findings of Chindah [20] in assessment of water quality of some creeks in Niger Delta. The temperature of these water bodies are believed to have been influenced by the intensity of sunlight. Variation of temperature in water bodies attributable to sunlight was reported to occur particularly in estuaries due to their general shallowness, which exposed the water and mudflats to sunlight [21]. The DO values measured along the creeks were within permissible limit of 4.0-10.0 mg/l as described by Boyd [18]. Depletion of DO in water can encourage the microbial reduction of nitrate to nitrite and sulphate to sulphide an indication of utilization by organic and inorganic compounds from domestic and industrial wastes. The DO values of $4-5 \mathrm{mg} / 1$ are essential for fish and aquatic life. This implies that the creeks in this study having DO values above $4 \mathrm{mg} / 1$ are expected to sustain aquatic life [18] The salinity values recorded at the various sampling sites during the study showed that the values ranged from $7.00 \%$ to $14.20 \%$. Similar values have been reported by Chindah [22] in the main channel of the Bonny estuary, in the rainy season, when fresh water discharge was heaviest. Similarly, Ngah et al. [23] also reported that low salinity in bonny tidal basin is influenced by fresh water discharge.

The objective of a racial study is to establish, with some degree of confidence, the taxonomic identity of a species in differently located bodies of water. This becomes more important in the utilization of its fishery resources because the quality of the existing strain is very crucial for any successful breeding programme. In this study, meristic and morphometric features were used as they still remain dependable tools to characterize fish species especially on the field and they are sensitive to any environmental changes [24]. The fairly constant values of fin rays observed S.melanotheron in the three creeks agree with the findings of Reed et al. [25] that fin rays of the tribe Tilapiini do not vary much. The significant variations in total length (TL), standard length (SL), head length (HL), caudal peduncle length (CPL) and maximum body depth (MBD) recorded in this study, might have occurred as a result of environmental fluctuations, especially water temperature and salinity [27].

The differences in the morphological characters of specimens are supposed to be in association with aquatic ecosystems from which they originated [28]. Beacham [29] stated that the variation among populations of fish characters could be induced by ecological factors interacted with fundamental genetic roles. In this study, the values of head length varied significantly between the fish sampled from Buguma creek and other creeks. This observation reflects the findings of Turan et al. [30] who reported that the differences between populations of Tilapiine species were reflected mostly in head measurements. In this study, the significant differences observed in the morphometrics may have occurred as a result of isolation caused by variation in these ecological factors in the two habitats. With comparable studies from other West African waters [25, 31, 32].

Fish has been said to demonstrate greater variances in morphological traits both within and between populations of species than any other vertebrates [33]. Dunham et al. [34] has shown that morphometric parameters can be highly variable among and within nonspecific populations, either correlating with geographical and habitat variation or having a genetic component, based on differences among groups in a common environment. Eyo [35] had highlighted environmental conditions such as food abundance and temperature as causes of fish high morphological plasticity. Also, Solomon et al. [36] had also suggested genetic variation caused by inbreeding, crossbreeding and other practices that can dilute gene pool as the major cause of differences in cultured and wild African catfish. However, the marked differences of morphology in the present study may be linked to genetic differences of the species. 


\section{Conclusion}

In this study, meristics, and morphometric, features were used as they still remain dependable tools to characterize fish species. The values of fin rays in S.melanotheron were constant in all the three creeks. The significant variations in head length, (HL), body depth (MBD), and caudal penduncle depth (CPL) were observed. This might have occurred as a result of: environmental fluctuations. It is therefore suggested that for the farming programmed of this species, the brood stock from Buguma Creek should be preferred based on head, body and caudal peduncle depths data.

\section{References}

1. Akinrotimi OA, Cliffe PT, \& Ibemere IF. Integration of rural aquaculture into small scale farming in Niger Delta region of Nigeria. Global Approaches to Extension Practice. 2011;7(1):43-48.

2. Ugwumba AAA. Food and feeding habits of the juveniles of some culturable fish species in Nigeria. Nigerian Institute for Oceanography and Marine Research Technical Paper No. 31.1988;24.

3. Ugwumba AO. and Ugwumba AAA. On the biology of the black jaw tilapia, Sarotherodon melanotheron (Ruppell), in a tropical freshwater lake. Niger J Res Rev Sci. 1993;1:12-25.

4. Yakubu A, Okunsebor AS. Morphometric differentiation of two Nigerian fish species (Oreochromis niloticus and Lates niloticus) using principal components and discriminant analysis. Int J Morphol. 2011;29(4):1429-1434.

5. Oyekanmi BO. A comparative racial studies of Sarotherodon melanotheron (Ruppell) in Nigerian brackish and fresh water environment. (BSc. Research Report.) University of Agriculture, Abeokuta, Nigeria. 2000;39.

6. Elliott NG, Haskard K, Koslow JA. Morphometric analysis of orange roughy (Hoplostethus atlanticus) off the continental slope of southern Australia. Journal of Fish Biology. 2015;46:202-220.

7. Mamuris Z, Apostolidis AP, Panagiotaki P, Theodorou AJ, Triantaphllidis C. Morphological variation between red mullet populations in Greece. J Fish Biol. 1998;52:107-117.

8. Marcus 0. Morphometric and meristic data for Ilisha africana (Bloch) (Pisces: Clupeidae) in Nigeria coastal waters. Biologia Afr. 1986;3(12):15-23.

9. Mwanja MT, Muwanika V, Nyakaana S, Masembe C, Mbabazi D, Justus Rutasire J, et al. Population morphological variation of the Nile perch (Lates niloticus, L. 1758), of East African Lakes and their associated waters. African Journal of Environmental Science and Technology. 2011;5(11):941-949.

10.Abowei JFN. The Morphology, Abundance, Condition Factor and Length-weight Relationship of E. fimbriata (Bowdish 1825) from Nkoro River Niger Delta, Nigeria. Advance Journal of Food Science and Technology. 2009;1(1):51-56.

11.Swain DP, Foote CJ. Stocks and chameleons the use of phenotypic variation in stock identification. Fish Res. 1999;43:113-128.

12.Holden M, Reed W. West African fresh water fish, 1st edn. West African Nature Handbooks, Longmans. 1972;67.

13.Fitzsimmons K. Future trends of tilapia aquaculture in the Americas. In: Baton Tilapia Aquaculture in the Americas, Vol. 2. (Costa-Pierce, B.A and J.E. Rakocy, (Eds.). Rouge, Louisiana: World Aquaculture Society.

\section{$2000 ; 123: 12-34$}

14.Gabriel UU, Anyanwu PE, Akinrotimi 0A. Comparative Effects of Different Acclimation Media on Haematological Characteristics of Brackish water tilapia, Sarotherodon melanotheron (Rupell, 1852). Journal of Fishery International. 2007;2(3),195-199.

15.APHA. Americam Public Health Association: Standard Methods for the Examination of Water and Waste Water. 16th Edition APHA, Washington DC, U.S.A. 1998.

16.Imevbore AMA. The Investigation of Faecal Pollution in the Surface Water of the Niger Delta of Nigeria. Final Report Niger Delta Basin Development Authority. 1983:4-94.

17.Agbozu IE, Emperor J. Effect of waste Dump on Water Quality of Central Sombreiro River in the Niger Delta, Nigeria. Journal of Agricultural and Environmental Engineering Technology. 2004;1:48-54.

18.Boyd CE. Water Management for Pond Fish Culture. Elsevier Scientific Publications, Amsterdam Development on Aquaculture and Fisheries Science. 1982;231.

19.Chindah AC, Hart AI, Uzoma A. Prepiphton associated with submerged macrophyte (Crinium nations) in the Upper reaches of the New Calabar River, Niger Delta. Journal of Sustainability. 1999;23:112-120.

20.Chindah AC. The spatial and temporal variations in the epipelic algal community of Bonny/New-Calabar estuary of the Niger Delta. Ph.D. Thesis. 1998.

21.Agbozu IE, Izidor UA. Assessment of water quality in Niger Delta: A Case study of Ogba/Egbema/Ndoni Local Government Area Rivers State. Journal of Agricultural and Environmental Engineering Technology. 2004;1:42-47.

22.Chindah AC. "The effect of industrial activities on the Periphyton community at the upper reaches of New Calaber River, Niger Delta, Nigeria". Water Research. 1998;32(4):1137-1143

23.Ngah SA, Braide S, Dike CC. Physico-Chemistry of Elechi Creek in the Upper Bonny Estuary, Rivers State, Nigeria. Journal of Geoscience and Environment Protection. 2017;5:181-197. DOI: 10.4236/ gep.2017.58015

24.Chambers RC. Phenotypic variability in fish populations and its representation in individual based models. Transactions of the American Fisheries Society. 1993;122:404-414.

25.Reed W, Burchard J, Hopson AJ, Jenness J, Yaro I. Fish and Fisheries of Northern Nigeria. Gaskiyya Corporation, Zaria. 1967;226.

26.Ajao EA, Fagade SO. A study of the sediments and communities in Lagos Lagoon, Nigeria. Oil Chem. Pollut. 1990;7(2):85-117.

27.Falk TM, EK Abban, W Villwock, L Renwrantz. Haemoglobin variations in some tilapiine species (Teleostei, Cichlidae) of the genera Oreochromis and Sarotherodon. In J E Agnese (ed.). 1998;148-152.

28.Beacham TD. Meristic and morphometric variation in pink salmon (Oncorhynchus gorbuscha) in southern British Columbia and Puget Sound. Canadian Journal of Zoology. 1985;63(2):366-372.

29.Turan C, M Oral, B Ozturk, E Duzgunes. Morphometric and meristic variation between stocks of bluefish (Pomatomus saltatrix) in the Black, Marmara, Aegean and northeastern Mediterranean Seas. Fisheries Research 2006;79:139-147.

30.0moniyi IT. A comparative study of morphometric variations in Tilapia zillii (Gervais) from three man-made lakes around Ibadan, Nigeria. Biosci Res Commun. 1997;9(4):225-229. 
31.0moniyi IT, Agbon AO. Morphometric variation in Sarotherodon melanotheron (Pisces: CICHLIDAE) from Brackish and Freshwater habitats in South West Nigeria. Proc. of the 29th Annual Conference of the Genetics Society of Nigeria, Oct. 11- 14, 2004, Abeokuta, Nigeria, University of Agriculture. 2004:20-22.

32.Eyo JE. Congeneric Discrimination of Morphometric Characters among Members of the Pisces Genus: Clarias (Clariidae) in Anambra River, Nigeria. The Zoologist. 2003;2(1):1 -17.

33.Currens KP, Sharpe CS, Hjort R, Schreck CB, Li HW. Effects of different environments on fish morphology. Journal of Science. 2016;45:127134
34.Dunham AE, Smith GRand Taylor JN. Evidence for ecological character displacement in western American catostomic fishes. Evolution. 1979;33(3):877-896. DOI: 10.1111/j.1558-5646.1979.tb04742.x

35.Solomon SG, Okomoda VT, Ogbenyikwu AI. Intraspecific morphological variation between cultured and wild Clarias gariepinus (Burchell) (Clariidae, Siluriformes). Archives of Polish Fisheries. 2015;23(1):5361. DOI: $10.1515 /$ aopf-2015-0006 